\title{
The category of the culture of work as vocation: The proposal of the Evangelical Church in Germany for the current upheavals in the world of work
}

\begin{tabular}{|c|c|}
\hline $\begin{array}{l}\text { Author: } \\
\text { Piotr Kopiec }{ }^{1,2}\end{array}$ & \\
\hline $\begin{array}{l}\text { Affiliations: } \\
\text { 'Department o } \\
\text { Institute, Facul } \\
\text { John Paul II Cat } \\
\text { University of Lu } \\
\text { Poland }\end{array}$ & $\begin{array}{l}\text { f Ecumenical } \\
\text { Ity of Theology, } \\
\text { tholic } \\
\text { ublin, Lublin, }\end{array}$ \\
\hline $\begin{array}{l}{ }^{2} \text { Department o } \\
\text { Testament Stuc } \\
\text { Related Literat } \\
\text { of Theology an } \\
\text { University of P } \\
\text { Pretoria, South }\end{array}$ & $\begin{array}{l}\text { f New } \\
\text { dies and } \\
\text { ure, Faculty } \\
\text { d Religion, } \\
\text { retoria, } \\
\text { Africa }\end{array}$ \\
\hline $\begin{array}{l}\text { Research Proje } \\
\text { Project Leader } \\
\text { Aarde } \mathbb{1} \\
\text { Project Numbe }\end{array}$ & $\begin{array}{l}\text { ct Registration: } \\
\text { er: } 2334682\end{array}$ \\
\hline $\begin{array}{l}\text { Description: } \\
\text { This research is } \\
\text { research projec } \\
\text { Theology and } \vdash \\
\text { directed by Pro } \\
\text { van Aarde, Pos } \\
\text { Professor and } \$ \\
\text { Research Fello } \\
\text { Office, Faculty } \\
\text { and Religion, U } \\
\text { Pretoria. }\end{array}$ & $\begin{array}{l}\text { s part of the } \\
\text { ct, 'Biblical } \\
\text { Hermeneutics', } \\
\text { of. Dr Andries } \\
\text { st Retirement } \\
\text { Senior } \\
\text { w in the Dean's } \\
\text { of Theology } \\
\text { Jniversity of }\end{array}$ \\
\hline $\begin{array}{l}\text { Corresponding } \\
\text { Piotr Kopiec, } \\
\text { petrko@kul.pl }\end{array}$ & s author: \\
\hline $\begin{array}{l}\text { Dates: } \\
\text { Received: } 17 \mathrm{~N} \\
\text { Accepted: } 27 \mathrm{~J} \\
\text { Published: } 14 \mathrm{~S}\end{array}$ & $\begin{array}{l}\text { May } 2021 \\
\text { une } 2021 \\
\text { Sept. } 2021\end{array}$ \\
\hline $\begin{array}{l}\text { How to cite thi } \\
\text { Kopiec, P., } 2021 \\
\text { of the culture o } \\
\text { vocation: The } p \\
\text { Evangelical Chu } \\
\text { Germany for th } \\
\text { upheavals in th } \\
\text { work', HTS Teol } \\
\text { Theological Stu } \\
\text { a6844. https:// } \\
\text { 10.4102/hts.v7 }\end{array}$ & $\begin{array}{l}\text { is article: } \\
1 \text {, 'The category } \\
\text { of work as } \\
\text { proposal of the } \\
\text { urch in } \\
\text { le current } \\
\text { e world of } \\
\text { logiese Studies/ } \\
\text { ldies } 77(2) \text {, } \\
\text { doi.org/ } \\
7 \text { i2.6844 }\end{array}$ \\
\hline Read online & \\
\hline 回店回 & $\begin{array}{l}\text { Scan this QR } \\
\text { code with your } \\
\text { smart phone or } \\
\text { mobile device } \\
\text { to read online. }\end{array}$ \\
\hline
\end{tabular}

The current upheavals in the world of work become one of the central themes of the reflections in social sciences. Many authors raise questions about the results of shrinking employment, growing digitalisation, demands of new skills meeting the challenges of the oncoming economic order, to mention just a few from a broad range of processes and phenomena. It is also an essential motive of the Christian Churches' social teaching, for instance, for the Evangelical Church in Germany (Evangelische Kirche in Deutschland [EKD]). The church offers a comprehensive and relevant vision of human work, linking the social and political teaching of the Protestant Reformation and contemporary theological, sociological and sociopolitical conceptions. The article aims to outline the evangelical interpretation of the transformations in human work and asks how inspirations of Reformation theology are applied to today's critical issues concerning these transformations. It also discusses the category of the culture of work as vocation and considers its potential for a broader discussion on the topic. The primary sources of the reflection are the relevant documents of the EKD (Denkschrifts), recently published.

Contribution: The theological interpretation and proposals of the Evangelical Church in Germany contribute to the global discussion on the transformations in the sphere of work, particularly when examining the sociological and political potential of the category of the culture of work as vocation. The research addresses the focus and scope of the journal for the promotion of multidisciplinary aspects of studies in the general theological area.

Keywords: human work; Evangelical Church in Germany; digitalisation; culture of work; vocation; theology; sociology.

\section{Introduction}

Human history is a history of human work. When looking back into the past, it is a history of slavery, serfdom, alienation and toil on the one hand and a history of human creativity, art, invention and industry on the other. Human work is both a source of suffering and pain and, conversely, a source of human blessing and happiness. This ambiguity is a rudimentary experience of every human being, and, as such, it is a matter of human reflection. There are many examples of how Philosophy, Theology, social sciences consider and define human work. Aristotle's teaching on the hierarchy of human activities, Marx's notion of alienation or Hannah Arendt's distinction between work, labour and action are some of the well-known concepts.

Today this ambiguity gains new perspectives while not removing the previous ones. It touches every point of the list of hallmarks of the contemporary world. It reflects in the questions asking about the social consequences of technological progress, the ways of distribution of the state's income or the results of the cultural patterns of consumptionism. There is something ambiguous in the forecasts of John Maynard Keynes or Jeremy Rifkin who prophesied the end of the coercion of work (Skidelsky \& Skidelsky 2013:18). The future of work appears rather precarious, even though we are flooded with various economic and sociological scenarios of the oncoming changes.

Moreover, the question of work is a derivative of broader discussions on the future of capitalism. For some, it is one of the strongest cards in the critique of the current socio-economic order and in searching alternatives of it, whereas, for others, it is another proof of the adaptation ability of capitalism.

Copyright: (C) 2021. The Authors. Licensee: AOSIS. This work is licensed under the Creative Commons Attribution License. Note: Special Collection: Scholarly Voices, sub-edited by Yolanda Dreyer (University of Pretoria). 
Such discussions are also conducted in the theological field. Both Churches and theological expert teams reflect on the meaning and value of human work in today's rapid economic transformation, trying to shed light on the issue from the perspective of the Bible and theological traditions, regardless of confession. In many cases, it is a very valuable contribution, for instance, the utterances of the Evangelical Church in Germany (Evangelische Kirche in Deutschland [EKD]). The EKD has a long tradition of publishing the documents (Denkschrifts) that present the Church's teaching on a given question. Careful research of their content shows the significance of the topic of today's changes in labour for the German theologians. In recent years several extensive texts were published, raising this issue from different aspects. Usually, they embrace theological, sociological and economic conclusions and impress with the accuracy of their diagnoses. They adapt the social and political teaching of the Reformation to the current circumstances by endeavouring to update Luther's vocational ethics and theological vision of the Christian society as a system of interrelated functions ascribed to every Christian. As a result of this updating, they propose the 'culture of work as a vocation', a very interesting and relevant teaching that, if adopted, would address both the threats and opportunities of the contemporary challenges.

The article does not intend to make a careful exegesis of the texts of the Church. Instead, it will look at the visions and proposal elaborated by the EKD from the context of the systemic theory of society and the Protestant social and political teaching. Thus, it outlines the evangelical interpretation of the transformations of human work and asks how inspirations of the Reformation theology are applied to today's critical questions in reference to work. This general research aim includes the following research questions: What are the Protestant social and political teaching's hallmarks concerning work? How do they refer to the contemporary socio-economic transformations? What are specific proposals of the evangelical theologians for meeting the challenges of today's economy and technological progress? Moreover, more specific, what is the culture of the work as vocation? The key sources of reflection are the selected documents of the EKD, issued in the last decade.

\section{Martin Luther's sociopolitical teaching}

There are myriads of volumes considering Luther's political and social teaching. Thus, we need only a glimpse that would be a cornerstone for further reflections. Luther's concepts were obviously embedded in the Middle Ages' vision of power and relations between man, state and the church. However, there are the points in this concept that are regarded as one of the sparks of modernity. Obviously, it is about vocational ethics, and the vision of society relied on the principle of the universal priesthood; after all, the first may be regarded as a derivative of the latter. There is no need to repeat the well-known assumptions of Max Weber or Talcott Parsons about the genetic interdependence between
Protestantism and modernity; to recap their theories, one could refer to the short description of the Protestant Reformation written by the American sociologist:

The Reformation was an exceedingly complex religiosocial movement. Weber, nevertheless, suggests that it can be divided into two principal branches, the Lutheran and the Calvinist. The Lutheran branch represented the more inward, spiritualistic interpretation of emancipation from the institutionally 'objective' Catholic Church. Its primary concern was with the soul of the individual Christian believer. The Calvinist branch, on the other hand, emphasised the Christian community as a corporate entity, a fully legitimised descendant of the early and medieval Church, and the bearer of the main Christian heritage. (Parsons 1984:502)

Nevertheless, in the opinion of Parsons, both branches brought about the change that 'was not primarily a downgrading (religiously speaking) of the clergy, both regular and secular, but rather an upgrading of the laity' (Parsons 1984:501).

I did not quote this Parsons' utterance accidentally. The American sociologist translated Weber's 'Protestant Ethics and the Spirit of Capitalism' and thus sparked the interest in Weber's oeuvre in American academia. However, more important is that his functionalist theory of society, so overwhelming in sociology in the mid-20th century, has echoed Luther's vision. Parsons (2001) conceives society as:

$[A]$ plurality of individual actors interacting with each other in a situation, which has at least a physical or environmental aspect, actors who are motivated in terms of a tendency to the 'optimisation of gratification' and whose relation to their situations, including each other, is defined and mediated in terms of a system of culturally structured and shared symbols. (p. 5)

When coming down from the summits of this sociological vernacular, one could state, that in Parsons' definition, the social system embraces different social roles and social positions, furthermore, an acceptance of rights and duties stemming from this diversification, and finally, norms and values shared in the given system. It is thus sociology of social order and social balance (Szacki 2012:812).

It is striking how much Parsons' theory and Luther's social teaching have in common, obviously having in mind historical contextualisation. It seems that functionalist sociology helps to comprehend the latter when applying widespread modern terms, just as a system, to the former images of society.

In the very strict sense, Luther did not conceive an original social theory. He rather adopted what he had at hand, such as the Augustinian teaching on the two kingdoms organised around values or the conservative vision of the social structure divided into social classes and social roles ascribed to every social position (Szacki 2012:43). On the other hand, the theory was somehow intrinsically revolutionary, in the sense that it relied on a theological 
egalitarianism of the principle of the universal priesthood. This egalitarianism was pointed out by many philosophers, for instance, Hegel and today's Charles Taylor. Luther was primarily a theologian, and all non-theological dimensions of his teaching, whether political or social, were subordinated to theology.

Consequently, this theological foundation built a systemic and homogenous vision of the social structure consisting of Christians who are called to fulfil their social roles (vocations), as equal before God. Perhaps the best-known utterance of Luther (1915) that illustrates this topic derives from his early work 'To the Christian Nobility of the German Nation':

A cobbler, a smith, a farmer, each has the work and office of his trade, and yet they are all alike consecrated priests and bishops, and every one by means of his own work or office must benefit and serve every other, that in this way many kinds of work may be done for the bodily and spiritual welfare of the community, even as all the members of the body serve one another. (p. 3)

Obviously, this systemic feature of the theological vision of society must be accomplished by other elements of Luther's teaching: anthropology of the Christian person who lives in the tension between internal freedom and external dependence ("The Christian individual is a completely free lord of all, subject to none; the Christian individual is a completely dutiful servant of all, subject to all') (Luther 2016:10), and the political division of two kingdoms: earthly and spiritual. The list of the relevant motives of Luther's theology is far longer. Nevertheless, it appears evident that any particular function and any particular calling are equal before God in the perspective of this teaching. Important is the way they are fulfilled, as it confirms that the given person answers to the gift of justification. Through the work, a Christian realises his or her vocation, confirms his or her faith, contributes to the common good of the given community or society; moreover, everyday work is a manifestation of the love to neighbours. Max Weber said it in a simple sentence: 'Work in the calling is $a$, or rather, the, task set by God' (Weber 2005:45). This task is a foundation of the social system from the Christian perspective.

Theologians must ask about the relevancy of this specific systemic approach in today's transformations. Is it eligible to apply it to the sphere of work, so dispersed and so flexible because even contemporary sociology seems to give up on building a systemic vision of society? Does Luther's vision still matter? Is it not so that the transformations in the sphere of work bring about failures in the social system? Moreover, does Marx's term of alienation not gain new, broader and theological (a paradox) significance, as the individual is often deprived of the work as vocation (defined in Luther's sight) because of these transformations? Perhaps it is otherwise, and these changes give new opportunities to create the sphere of work according to the paradigm of vocation? Perhaps flattened hierarchies in the companies, networked and knowledge-based economy and technical conditions will help foster a culture of work as vocation?

\section{The Evangelical Church in Germany about today's socio-economic reality}

There are at least five documents of the EKD recently published that could be regarded as a very relevant source of the description of today's socio-economic order, with the strong emphasis on the work: 'Evangelical Responsible Elites' (Evangelische Verantwortungseliten. Eine Orientierung), 'Solidarity and Self-determination in a Changing Working World' (Solidarität und Selbstbestimmung im Wandel der Arbeitswelt), 'Good School from the Evangelical Perspective' (Gute Schule aus evangelischer Sicht. Impulse für das Leben, Lehren und Lernen in der Schule), 'In the Path of Righteousness there is Life' and 'Like a high wall, cracked and bulging'. They are not merely a bare illustration of our reality; rather they strive to outline relevant proposals of a 'good order' in society, economy, politics and culture. The given list is obviously far richer; there are indeed many other documents that would be more or less relevant to the discussed topic.

Before making a more thorough presentation, one should provide several introductory (and simultaneously conclusive) remarks. Firstly, even though the documents are set in the German context, they may be globally regarded as an exemplification of a universal programme for the future of our world. Secondly, when declaring and defining certain values of the social order, they put the emphasis on the socioethical dimension of the given processes and thus contribute to the global discussions on the answers for the crucial challenges for the world. Thirdly, the EKD manifests a systemic vision of the society, and it is a 'system of inclusion', as far as possible embracing entities and interdependencies of the particular aspects of society. This vision is given not only in the above-mentioned documents, but it is also a dominant theological discourse of the church and has an ecumenical impact. In many cases, the EKD goes hand in hand with the Catholic Church, which reflects the tradition of publishing joint agreements on the given topics. Fourthly, the evangelical discourse on the socio-economic order seems to be set today in an interplay between radical anti-systemic approaches from both sides: on the one hand, it is a milieu of the Radical Reformation (Kopiec 2019:188), a theological circle fighting with the civilisation of capitalism; on the other it is a social laissez-faire attitude, rejecting the Church's involvement in a reflexive development of society, economy and politics.

As already stressed, the sphere of work is a central theme of this discourse. It sees human work as being entangled in enormous and robust processes that are entirely changing existing structures and relations in society and require a common and systemic answer from the social institutions: state, education, family, culture and the church. The main causes of these transformations are both rapid technological progress and false models of society imposed upon by different political strategies that reduce the influence of the particular social institutions and their cooperation. Consequently, contemporary societies may fail to adopt the changes brought about by technology (one could evoke rudimentary observation of the cultural lag of William 
Ogburn) and may be more and more vulnerable to the inequalities and exclusions that push off entire social groups on the margins. It is a picture that is far from the systemic vision of the evangelical theologians.

The theologians from the EKD employ a scheme consisting of the following questions: how it is now (the current state of affairs)? how it should be (a general goal)? and what measures must be used to approach this goal? The first stage is regarded as an unconstrained economic and technological development that seriously threatens the social balance and social order. Its symptoms are listed as follows: 'the extreme accumulation of capital, exploitative and undignified working conditions, health hazards, the unsustainable use of natural resources and the formation of monopolies and oligopolies' (Solidarity and Self-determination 2015b:9). The second question refers to the two dimensions: to an individual as a single social entity and the whole society, in the way that the good of both is intrinsically intertwined. Thus, the general goal of the evangelical vision is:

[A] society of just participation, in which everyone is able to realise his or her abilities, and in which the self-interest is tied into an order that promotes the common good. (Solidarity and Self-determination 2015b:8)

\section{Such a participative society needs the promotion of a:}

[C]ompetitive basic social order, anchored in a social partnership, one in which the goods and services that people need are developed, produced and distributed based on entrepreneurial activity in cooperation with all. (Solidarity and Self-determination 2015b:8)

Finally, the third question considers examples of values and principles regarded as means to achieve this goal.

This general scheme reflects in both comprehensive and detailed reflection. The presentation of it might stem from the specific historical line presenting changes in the significance of work. This line stretches between four points: Biblical teaching, the teaching of the Protestant Reformation, the consequences of modernity and the contemporary shift marked by a range of processes unknown before. This four stage division helps to comprehend both the evangelical vision of work as vocation and an interruption in the meaning of work in the modern epoch.

The line comes through from the wider to narrower meanings. In the Bible, work is regarded as a human contribution to God's creation, and through the work human being is called to be a co-manager. Work does not refer to merely paid and professional labour, rather to many fields of human activity, as family, neighbourhood, religious and political community. Consequently, it is undertaken in a community (just to remind Durkheim's distinction between mechanical and organic solidarity). Finally, work has limits, manifested in the Sabbath rest. The Biblical vision was deepened and developed in the second stage, marked by the Reformation and already mentioned vocational ethics.
The Enlightenment and the Revolutions: industrial revolution in England and political revolution in France and the United States set the frameworks for modernity and, consequently, new meanings of work. On the one hand, it was the Marxist absolutisation of work; on the other, industrialisation reduced the sphere of human activity to the paid work. Contemporary epoch denoted as postmodernity or as the late modernity (as Anthony Giddens insists that 'rather than entering a period of postmodernity, we are moving into one in which the consequences of modernity are becoming more radicalised and universalised than before') (Giddens 1996:3), is a time 'in-between'. Authors who describe it put stress on the cognitive and ethical relativism and flexibility of social structures (if speaking about structures at all). It is a time of the fourth industrial revolution, the emergence of the postmaterial and post-secular culture and worldviews and the epistemological shift declared by the postcolonial theory. It is a time of new elites and deepening socio-economic divisions.

This description might be a background for the factors of 'a deep upheaval' of the working world that were distinguished by the theologians from the EKD. They list processes such as digitalisation, globalisation, the interconnectedness of the markets and the international division of labour (Solidarity and Self-determination 2015b:22). All of them rapidly change the relations in the world of work while enforcing growing flexibility, greater pressure on economic adaptation and increasing competition, both locally and globally. Moreover, a specific result of these processes, especially digitalisation, is an overcoming of (or blurring) the boundaries of time and space. It also reminds somehow the theory of Anthony Giddens referring to late modernity as the process of dislocation of space from the place and disembodying of social systems (when defining it as the 'lifting out of social relations from local contexts of interaction and their restructuring across indefinite spans of time-space') (Giddens 1996:19).

The given list of the transformative factors converges with a new economy that is more and more often denoted as Industry 4.0 or the fourth industrial revolution. Just to remind, the latter term means a big and systemic change of society that Klaus Schwab (2016) describes as follows:

The fourth industrial revolution, however, is not only about smart and connected machines and systems. Its scope is much broader. Occurring simultaneously are waves of further breakthroughs in areas ranging from gene sequencing to nanotechnology, from renewables to quantum computing. It is the fusion of these technologies and their interaction across the physical, digital and biological domains that make the fourth industrial revolution fundamentally different from previous revolutions. (p. 12)

It appears obvious that the emergence of this new economic model has a profound impact on the sphere of work. In a narrow sense, it reflects in increasing demand for new skills, in a more sparing use of non-renewable resources, in expanding consumer choices, in loosening up traditional work rhythms and in more flexible working conditions. The 
last point links with the spreading of the new form of employment. The theologians of the EKD present them when referring to the binary model of normal and atypical working conditions and explain the first as a permanent, full-time job with social security obligations, whereas the latter as rather a part-time job, without the full right to social protection. Even though they argue that atypical working conditions should not be equated with precarious work and, therefore, with the spreading of the precariat, they clearly discern a causal relationship of both (Solidarity and Selfdetermination 2015b:23).

There is also a wider sense that refers to the changes occurring in society, family and in individual persons. On the one hand, this emerging economy seems to offer more space for a balance between work and other aspects of human life. On the other, it contributes (as already mentioned) to employment insecurity; thus, it renders social life less stable:

The shifts and changes to the working world can also result in greater psychological strain. More people now suffer from mental health issues than had previously been the case. While these social changes correspond with a high degree of independence and recognition in both professional and private terms, they can also involve a less reliable and stable basis for people's livelihoods. (Solidarity and Self-determination 2015b:23)

The theologians accomplish all these observations by pointing out the areas of potential conflict in the sphere of work. In most cases, they relate to factors that bring about change, such as globalisation and digitalisation and consider what the results of these processes are in societies, the economy and the family. There is no place in this short article to list given examples of conflicts, yet it should be observed that all of them required a careful early-stage policy of development and inclusion.

Moreover, economic and social transformations require changes in models of upbringing. Obviously, the principal goal of education is not merely training for effectively performing work. Rather education should lead individual persons to recognise the world and her or his place within it (Gute Schule aus evangelischer Sicht 2016:4). The theologians of the EKD present such an inclusive programme of education for the society meeting oncoming challenges in the programme of 10 crucial messages to school (Botschaften zur Schule). It shows the evangelical tradition of education in reference to schools' primary goals (as the institutions of education) in the contemporary pluralistic society. Particularly important are the ninth and tenth messages. The first of them emphasises the role of the school in shaping a balance between structures and flexibility (Schulreformen bringen die Spannung zwischen Strukturen und Flexibilität in eine Balance), the latter in the proper interdependency and cooperation between school and society (Die Gesellschaft pflegt, stützt und begleitet die Schule). Both points reveal a striving for a social system that would efficiently adopt the revolutionary changes in technology, economy, culture and society (Gute Schule aus evangelischer Sicht 2016:21).

\section{The category of the culture of work as vocation}

There is merely one sentence in the investigated texts of the evangelical theologians that mention the category of the culture of work as vocation. However, even though this notion seems to be marooned in the content, it unleashes a vast potential of answers meeting the contemporary challenges of the sphere of work. In order to shed more light on its specific meaning, let us make more general references to the sociological theory of culture.

It is a rudimentary tenet that culture consists of values, norms, cultural patterns and principles. Obviously, culture was defined differently - it is enough to evoke the famous typology of Alfred Kroeber and Clyde Kluckhohn, who distinguished six types of definitions of culture already in the 60 s of the 20th century. Yet regardless of these differences, one can point out at a shared conviction that culture is composed of integrated and inherent elements such as beliefs, norms and values that manifest in social life and determine it. This simplified description may be supported by Manuel Castells, who holds that: 'By culture I understand a set of values and beliefs informing behaviour. Repetitive patterns of behaviour generate customs that are enforced by institutions, as well as by informal social organisations' (Castells 2002:36). Likewise, Anthony Giddens explains that culture is a system of elements shared by members of a given society so that they can cooperate and communicate with each other (Giddens 2013:22). Very suggestive, although later criticised, was Talcott Parsons' sociological paradigm of the AGIL - acronym referred to the four functional imperatives: adaptation (A), goal attainment (G), integration (I) and latency (L), that are, as Parsons argued, organising social system. The fourth of the distinguished imperatives refers to the cultural system, that is, to the latent processes and elements of reproduction of cultural patterns. It means that culture is a measure of maintaining the social system when shaping human motivation and managing tensions. American sociologist believed that this function should be taken up by such social institutions as families, churches or school (Szacki 2012:821).

So culture is to be understood as a system of values and norms that organise the life of groups and entire societies. How does this basic belief refer to the category of the culture of work as vocation, provided that the latter has a theological source? In order to answer this question, one must continue to examine the narration of the theologians of the EKD who claim that approaching today's changes, or even 'upheavals' in the world of work requires not merely technical decisions of the social politics but must rely on the solid socio-ethical foundation. Moreover, the Evangelical Church many times confirmed that she sees herself as inevitably called to take part in shaping the ethical basis of society. It is enough to mention the seventh article of the Augsburg Confession, and the sixth article of the Barmen Declaration, the document that is today declared as the source of the theological identity of the EKD: 
The Church's commission, which is the foundation of its freedom, consists in this: in Christ's stead and so in the service of his own Word and work, deliver to all people, through preaching and sacrament, the message of the free grace of God. ${ }^{1}$

More recently, the Church's ethical office has been highlighted in the document entitled 'Church of Freedom' (Kirche der Freiheit 2006:15), with an introduction written by Wolfgang Huber, then Bishop of Berlin. Huber regards today's evangelical ethical teaching as organised around the principle of responsible freedom (verantwortliche Freiheit): 'The foundation of our economic order is responsible freedom ... Freedom without responsibility disintegrates' (Like a High Wall 2009:4). Thus, free and responsible social life should be seen as the interdependence of participation and commitment.

Therefore, the values of freedom and responsibility are two sides of the one axiological coin that depicts the Christian attitude in both personal and collective dimension. Coming down from the more general to the more particular socioethical levels, one can easily comprehend the two crucial values the church refers to the sphere of work, namely solidarity and self-determination:

Through work, people participate in the forming of the world, and through their actions people carry out the responsibility for the world mandated to them by God. People as God's creatures, created in his image, are freed and commissioned to further develop God's creation in an ongoing process, particularly when it comes to carrying out the biblical commandment to protect it. Ideally people carry out this work in a profession, in which they are able to unfold their talents. This can only succeed, however, by cooperating with others, as work is something communal, for which people bear individual responsibility in the freedom that they are granted. Self-determination and solidarity are inextricably interconnected and therefore, from a Christian point of view, need to be taken into consideration by both employers and trade unions. (Solidarity and self-determination 2015b:49)

I decided to quote this long fragment in extenso, as it well summarises the intentions of the theologians to offer an ethical standpoint regarding the upheavals in work. It includes the anthropological teaching on human creation and vocation and the interdependence of individual and collective aspects of human life; it mentions the value of responsible freedom as the Christian socio-ethical attitude and interconnectedness of solidarity and self-determination, the specific values stemming from the Christian understanding of work. In other words, the socio-ethical basis of the evangelical interpretation of the sphere of work must rely on both solidarity and self-determination. Consequently, both values set the foundations for concrete principles regarding the work life.

The overarching one is the active participation of all people in the world of work, including just participation in gainful employment, providing a sufficient livelihood. Further principles refer to the individual and collective work, to the profession and cooperation, finally, to the conflicts in work. Yet all of them create an integral and comprehensive 1. See https://www.ekd.de/en/The-Barmen-Declaration-303.htm. proposal for the contemporary ethics of work. On the negative side, it warns against cognitive reductionisms such as treating work as an end in itself (and therefore against an absolutisation of work) or commodification of the workforce:

The workforce is not a good that can be traded freely. It remains indivisibly connected to the individual person, involves using up invaluable human energies and therefore needs to be protected. (Solidarity and Self-determination 2015:51)

On the positive side, the proposal emphasises the holistic vision of human 'good work' that is 'an integral part of a good life' (Solidarity and Self-determination 2015b:52). Such identification comprises at least three tenets: Firstly, good work opens the space for one's development and one's creativity. Secondly, it contributes to social cooperation, especially in the perspective of a growing division of labour. Finally, in contemporary society, good work must regain its 'non-gainful' meaning. It means that society must rerecognise and re-affirm the work in the family, childrearing, care work, voluntary work and activities of civil society.

The proposal outlined by the theologians of the EKD seems to refer to another and earlier presented concept of good work, which is promoted by the Conference of European Churches, especially through its participation in the Church Action on Labour and Life (CALL). The idea, although ecumenical, traces back to the Lutheran Church in Finland. It consists of the following 10 tenets:

(1) Good work produces things of real value; (2) Good work respects the dignity of every human being, women and men of all ages, as made in the image of God; (3) Good work gives service to your neighbour; (4) Good work gives the opportunity to fulfil your vocation and to get training; (5) Good work does not make too many demands on creation; (6) Good work gives at least a subsistence income and good working conditions; (7) Good work brings the possibility of influencing working practices and the rhythm of work; (8) Good work enables adequate rest and relaxation, health and safety; (9) Good work affirms for each member of the working community the right to participate in decision making and (10) Good work balances family life and paid work and gives lifelong security to both women and men. (Policy Paper on Good Work 2014:2)

Similar to the discussed evangelical teaching, this concept also stresses the interconnectedness of paid work, work in the family and work for society, and it reflects the systemic vision of society.

Even though both the concept of good work and the evangelical proposals concerning changes in perceiving work appear to be too general or too 'dreamy', they can provide a socio-ethical model helping to keep pace with technological progress. It refers mainly to the abovediscussed teaching of the Evangelical Church in Germany. The documents meticulously describe the functioning of the social institutions (obviously in the German context) and assess the instrument of social politics. They either draw a paradigmatic picture of the labour law, which must be seen as an expression of human dignity. From the dignity of work, they derive a distinction between rights taken from 
work and rights at work, both encompassing fundamental demands of employers concerning wages, participation in the decision-making in a company and active improvement of the social order through the activities of associations and trade unions.

There is no space in this article to carefully examine the sociopolitical instruments and models suggested by the theologians. Yet, one must state that the theological discourse of the EKD is an essential contribution to the global discussion of the transformation of labour. It is relevant to either the holistic and systemic vision of social order or the specific updating of the Lutheran vocational ethics.

The latter opens a wide space of likely interpretations. It primarily concerns the category of the culture of work as vocation, and it is this point that seems to be the most worthwhile and original idea of the theologians of the EKD. In light of the sociological theory, it is rudimentary that the changes in social systems require changes in culture. These profound upheavals that we face, the ones that are declared as an interruption of continuity (again Schwab), must be appropriately adopted by culture to avoid, or at least mitigate, the ruptures and tensions brought about by the above-mentioned factors of change. Culture of work as vocation offers a relevant vision of balance and harmony between individual and collective good, individual and collective commitment; it imposes a meaning to the everyday duties and warns against the commodification of human activity. Finally, it provides answers for the new challenges of privatisation and individualisation of work, which deprive one of responsibility for the society in which she or he lives. If we define culture as a system of values, believes and norms, we better comprehend that the culture of work as vocation includes the Christian belief of work as God's vocation and God's invitation to cooperate in the creative process; moreover, it encompasses values such as solidarity and selfdetermination that ensure right relationships in the economic activities and offers principles for social institutions. In such a cultural model, the human being is able and free to avoid alienation of her or his labour and to affirm her or his objectivity.

\section{Acknowledgements Competing interests}

The author declares that he has no financial or personal relationships that may have inappropriately influenced him in writing this article.

\section{Author's contributions}

P.K. is the sole author of this article.

\section{Ethical considerations}

This article followed all ethical standards for research without direct contact with human or animal subjects.

\section{Funding information}

The article was supported by the National Science Centre, Poland, nr 2018/31/B/HS1/01254.

\section{Data availability}

Data sharing is not applicable to this article as no new data were created or analysed in this study.

\section{Disclaimer}

The views and opinions expressed in this article are those of the author and do not necessarily reflect the official policy or position of any affiliated agency of the author.

\section{References}

Castells, M., 2002, The Internet galaxy: Reflections on the Internet, business, and society, Oxford University Press, Oxford.

Church Action on Labour and Life, 2014, Policy paper on good work 2014, viewed 10 May 2021, from http://www.ceceurope.org/wp-content/uploads/2015/12/1CALL_Policy_Paper_on_Good_Work_-fin.pdf.

Evangelische Kirche in Deutschland, 2006, Kirche der Freiheit. Perspektiven für die evangelische Kirche im 21. Jahrhundert. Ein Impulspapier des Rates der EKD, Kirchenamt der Evangelischen Kirche in Deutschland, Hannover.

Evangelische Kirche in Deutschland, 2009, Like a high wall, cracked and bulging. Statement by the Council of the Evangelical Church in Germany on the global financial and economic crisis, Church Office of the Evangelical Church in Germany, Hannover.

Evangelische Kirche in Deutschland, 2015a, Solidarität und Selbstbestimmung im Wandel der Arbeitswelt. Eine Denkschrift des Rates der Evangelischen Kirche in Deutschland (EKD) zu Arbeit, Sozialpartnerschaften und Gewerkschaften, Gütersloher Verlaghaus, Gütersloh.

Evangelische Kirche in Deutschland, 2015b, Solidarity and self-determination in a changing working world. A Memorandum of the Council of the Evangelical Church in Germany (EKD) on work, social partnership, and trade unions, Evangelische Kirche in Deutschland, Hannover.

Evangelische Kirche in Deutschland, 2016, Gute Schule aus evangelischer Sicht. Impulse für das Leben, Lehren und Lernen in der Schule, Kirchenamt der Evangelischen Kirche in Deutschland, Hannover.

Giddens, A., 1996, The consequences of modernity, Polity Press, Cambridge.

Giddens, A., 2013, Modernity and self-identity: Self and society in the late modern age, Polity Press, Cambridge.

Kopiec, P., 2019, 'Projekt radykalizacji Reformacji: Ulricha Duchrowa teologiczna krytyka współczesnego porządku społecznego i politycznego', Kultura i społeczeństwo 62(1), 187-203. https://doi.org/10.35757/KiS.2018.62.1.7

Luther, M., 1915, Open letter to the Christian nobility of the German nation concerning the reform of the Christian estate, transl. C.M. Jacobs, A.J. Holman Company, Philadelphia, PA, viewed 05 May 2021, from https://web.stanford.edu/ jsabol/ certainty/readings/Luther-ChristianNobility.pdf.

Luther, M., 2016, The freedom of a Christian, ed. T.J. Wengert, Fortress Press, Minneapolis, MN.

Parsons, T., 1984, 'Religion in postindustrial America: The problem of secularization', Social Research 51(1/2), 493-525.

Parsons, T., 2001, The social system, Routledge, Abingdon, VA.

Schwab, K., 2016, The fourth industrial revolution, World Economic Forum, Geneva.

Skidelsky, R. \& Skidelsky E., 2013, How much is enough. Money and the good life, Penguin Books, London.

Szacki, J., 2012, Historia myśli socjologicznej, Wydawnictwo Naukowe PWN, Warszawa. Weber, M., 2005, Protestant ethics and the spirit of capitalism, Routledge, London. 